\title{
Solder Joint Device
}

National Cancer Institute

\section{Source}

National Cancer Institute. Solder Joint Device. NCI Thesaurus. Code C50014.

A connection between objects formed by solder. 